\title{
Sheep production and agronomic performance of Lotus corniculatus under dryland farming
}

\author{
T.N. BARRY ${ }^{1}$, P.D. KEMP², C.A. RAMIREZ-RESTREPOํ AND N. LOPEZ- \\ VILLALOBOS $^{1}$ \\ ${ }^{1}$ Institute of Veterinary, Animal and Biomedical Sciences \\ ${ }^{2}$ Institute of Natural Resources, Massey University, Palmerston North
}

T.N.Barry@massey.ac.nz

\begin{abstract}
Lotus corniculatus (lotus) contains condensed tannins (CT; 25-35 g/kg DM), which reduce the microbial degradation of forage protein in the rumen and increase amino acid absorption from the small intestine. In grazing experiments at Palmerston North during the 1990s, sheep grazing L. corniculatus had superior wool production, body growth and ovulation rates (OR) relative to sheep grazing lucerne (Medicago sativa) or perennial ryegrass (Lolium perenne)/white clover (Tritolium repens) pasture. Polyethylene glycol (PEG) drenching studies showed that action of CT was responsible for a component of the increases in wool growth and OR, but not body growth, and increased milk yield in lactating ewes.
\end{abstract}

The 'Massey lotus' programme moved in 2000 to Riverside farm in the Wairarapa, where L. corniculatus is more agronomically suited, and its integration into dryland farming systems is being studied. We aim to develop systems that increase animal productivity whilst also reducing chemical input, notably of anthelmintic drenches.

In two experiments conducted over 12 weeks in spring, ewes and lambs grazing L. corniculatus without pre-lamb drenching had lower faecal egg counts (FEC) and lower dag scores than ewes and lambs grazing pasture. Also, liveweight gain (+44\%), weaning weight $(+26 \%)$ and wool production $(+32 \%)$ were greater for lambs grazing lotus. Weaned lambs grazing L. corniculatus over 14 weeks in summer grew faster than those grazing pasture ( $298 \mathrm{cf} .201 \mathrm{~g} /$ day) when regularly drenched. Reduction of anthelmintic drenching reduced the growth rates of lambs grazing L. corniculatus, but at $228 \mathrm{~g}$ /day this was still much faster than those grazing pasture (187 g/day). Lambs grazing $L$. corniculatus with restricted anthelmintic grew slightly faster than regularly drenched lambs grazing pasture.

In addition, ewes mated on L. corniculatus had greater ovulation rates, lambing $\%$ and weaning $\%$ (approximately 25\%) than ewes mated on pasture. Lamb weaning weight was unaffected by the ewes grazing $L$. corniculatus during mating, but mortality rate during the period from birth to weaning was lower for lambs that were conceived when their dams were grazing lotus.

Annual (dry matter) production under grazing averaged over two years (2000-2001), was 9.5 t/ha for $L$. corniculatus and $8.6 \mathrm{t} / \mathrm{ha}$ for pasture. The percentages of annual production that occurred in spring, summer, autumn and winter were 49, 40, 8 and $4 \%$, respectively, for $L$. corniculatus and 55, 30, 9 and $6 \%$, respectively, for pasture. L. corniculatus has potential as a specialist feed in dryland farming systems for use during mating to increase subsequent lambing percentage and to increase lamb growth while reducing anthelmintic use. The result is more lambs being drafted at an earlier age.

Key words: agronomy, body growth, condensed tannins, dry matter yield, Lotus corniculatus, reproduction, sheep, withdrawing anthelmintic, wool growth

\section{Introduction}

Interest in Lotus corniculatus (lotus) arises because of its content of condensed tannins (CT), which have been shown to react with forage protein during chewing to form tannin-protein complexes. These complexes reduce the microbial degradation of protein to ammonia in the rumen $(\mathrm{pH} \mathrm{6.0-7.0),} \mathrm{yet} \mathrm{release} \mathrm{the}$ protein under the acid conditions in the abomasum ( $\mathrm{pH}$ 2.5-3.5) and so have the potential to increase amino acid absorption from the small intestine of ruminants grazing CT-containing forages (Jones \& Mangan 1977; Barry \& McNabb 1999). Research on this topic during the 1980s focused upon defining the effects of CT upon nutrient supply using indoor studies, whilst in the 1990s field trials of 2-3 months duration were conducted to study the effects of CT 
upon animal production and animal health (Barry et al. 2001)

In 2000, Massey University transferred its nutritional research with L. corniculatus from Palmerston North to Riverside Farm, near Masterton in the Wairarapa, to study its integration into dryland farming using a systems approach. L. corniculatus is better adapted to dryland regions, where its annual and seasonal production match those of perennial pasture, than regions with high rainfall and heavy, fertile soil. In the high rainfall regions, L. corniculatus is less productive than perennial pastures, and is readily outcompeted by pasture species and their weeds, resulting in poor persistence.

We review both the animal and plant production that can be obtained from $L$. corniculatus, with particular emphasis on its performance under dryland farming and its integration into dryland farming systems. Integration of CT-containing forages into grazing systems may well be a research theme for the 2000 2010 era.

\section{Condensed tannins}

Condensed tannins are secondary compounds that are found in trace amounts $(1-2 \mathrm{mg} / \mathrm{kg} \mathrm{DM})$ in the leaves and stems of perennial ryegrass, white clover, red clover and lucerne, where their concentration is too low to affect nutritive value. In contrast, they are found at concentrations of $25-35 \mathrm{~g} / \mathrm{kg}$ DM in $L$. corniculatus and $75-85 \mathrm{~g} / \mathrm{kg}$ DM in L. pedunculatus (Terrill et al. 1992). Recent research has shown that the reactivities of $\mathrm{CT}$ differ between forages and depend upon their concentration, molecular weight and molecular structure (Barry \& McNabb 1999). The $\mathrm{CT}$ in L. corniculatus have been the most effective of all the forage CT studied in NZ for increasing amino acid absorption in sheep (Waghorn et al. 1987; Min et al. 2003). Thus, more grazing trials have been conducted with $L$. corniculatus in NZ in recent years than with any other CT-containing legume.

\section{Grazing studies at Palmerston North}

A summary of grazing trials involving $L$. corniculatus, which were conducted at Palmerston North (Massey University and AgResearch Aorangi) during the 1990s, is shown in Tables 1 and 2. These studies were conducted with and without oral supplementation with polyethylene glycol (PEG) (MW 3350), which binds and inactivates $\mathrm{CT}$, in order to deduce the proportion of the lotus effect that is due to CT. In the absence of PEG, both body growth and wool growth were greater for lambs grazing 'Goldie' L. corniculatus than for lambs grazing Orangi lucerne. Polyethylene glycol studies showed that the action of CT was responsible for the extra wool grown by lotus-fed lambs but was not responsible for their extra body growth. Lambs grazing lotus and lucerne ate similar amounts of forage, which was not affected by $\mathrm{CT}$ in L. corniculatus. In similar studies conducted with lactating ewes grazing L. corniculatus during spring, responses to PEG supplementation showed that action of CT in mid-lactation increased the secretion of milk and milk protein by 21 and $14 \%$ respectively (Wang et al. 1996b).

Relative to ewes that were mated on perennial ryegrass-based pasture, mating ewes for 6-8 weeks on $L$. corniculatus increased mean ovulation rate (OR) by $22 \%$, with CT responsible for approximately half of this (Table 2). The responses to CT were larger than this in the two trials where the ewes gained weight during mating, relative to the one trial where a small weight loss occurred during mating. In these three experiments, the ewes mated on L. corniculatus continued to graze this for a further 3 weeks after the end of mating.

\section{Grazing studies in the Wairarapa}

The first priority for integrating L.corniculatus into a whole farming system was to feed ewes during mating, because the period of supplementation is relatively short (6-9 weeks), but the effect produced lasts for the rest of the year. An example of this effect occurred when ewes were mated on $L$. corniculatus during the 2001 autumn, which increased scanning, lambing, docking and weaning percentages (Table 3, RamíirezRestrepo et al. unpublished). Mating on $L$. corniculatus also reduced lamb mortality between birth and weaning $(\mathrm{P}<0.05)$, even though no $L$. corniculatus was fed to the ewes after the first trimester of pregnancy. This result is being investigated further in current research.

The second priority for use of $L$. corniculatus in dryland farming was to simultaneously increase spring growth of lambs and reduce the requirements for anthelmintic drench, thus increasing the proportion of lambs drafted before the onset of hot weather in December/January (and hence before the possible onset of drought). Relative to ewes and lambs grazed on spring pasture, grazing ewes and lambs on L. corniculatus for 12 weeks during the 
Table 1 Voluntary feed intake (VFI), liveweight gain (LWG), carcass gain and wool growth in lambs (Experiments 1, 2 and 3) and dry ewes (Experiment 4) grazing the forage legume Lotus corniculatus (27-34 g CT/kg DM) and lucerne (0.3 g total CT/kg DM) during summer.

\begin{tabular}{|c|c|c|c|c|c|}
\hline & \multicolumn{2}{|c|}{ Lotus } & \multicolumn{2}{|c|}{ Lucerne } & \multirow[b]{2}{*}{ SE } \\
\hline & $\begin{array}{c}\text { CT } \\
\text { Acting }\end{array}$ & $\begin{array}{c}\text { PEG } \\
\text { Supplemented }\end{array}$ & $\begin{array}{c}\text { CT } \\
\text { Acting }\end{array}$ & $\begin{array}{c}\text { PEG } \\
\text { Supplemented }\end{array}$ & \\
\hline & \multicolumn{5}{|c|}{ Experiment 1 (1991-92; 27.9 kg LW'; 4.5 kg DM/lamb/day²)3 } \\
\hline VFI (kg OM/day) & 1.76 & $\mathrm{ND}$ & 1.65 & $\mathrm{ND}$ & 0.040 \\
\hline LWG (g/day) & 228 & $\mathrm{ND}$ & 183 & $\mathrm{ND}$ & 8.2 \\
\hline Carcass weight $(\mathrm{kg})$ & 20.4 & $\mathrm{ND}$ & 17.8 & $\mathrm{ND}$ & 0.82 \\
\hline \multirow[t]{2}{*}{ Fleece weight (kg) } & 2.78 & $\mathrm{ND}$ & 2.25 & ND & 0.091 \\
\hline & \multicolumn{5}{|c|}{ Experiment 2 (1994-95; 19.3 kg LW; 5.3 kg DM/lamb/day)4 } \\
\hline LWG (g/day) & 271 & 250 & $\mathrm{ND}$ & $\mathrm{ND}$ & 8.0 \\
\hline Carcass weight $(\mathrm{kg})$ & 21.1 & 19.8 & $\mathrm{ND}$ & $\mathrm{ND}$ & 0.57 \\
\hline \multirow[t]{2}{*}{ Fleece weight $(\mathrm{kg})$} & 1.75 & 1.78 & $\mathrm{ND}$ & $\mathrm{ND}$ & 0.067 \\
\hline & \multicolumn{5}{|c|}{ Experiment 3 (1992-93); 22.4 kg LW; 2.5 kg DM/lamb/day)5 } \\
\hline Rumen ammonia (mg N/1) & 255 & 370 & 555 & 535 & - \\
\hline VFI (kg OM/day) & 1.19 & 1.20 & 1.32 & 1.34 & 0.056 \\
\hline LWG (g/day) & 203 & 188 & 185 & 178 & 5.8 \\
\hline Carcass gain (g/day) & 79 & 75 & 68 & 63 & 2.9 \\
\hline \multirow[t]{2}{*}{ Wool growth (g/day) } & 12.1 & 10.9 & 10.8 & 10.2 & 0.39 \\
\hline & \multicolumn{5}{|c|}{ Experiment 4 (1995-96; 54.0 kg; 1.3 kg DM/ewe/day)6 } \\
\hline Rumen ammonia (mg N/1) & 221 & 278 & $\mathrm{ND}$ & $\mathrm{ND}$ & 8.5 \\
\hline VFI (kg OM/day) & 1.23 & 1.20 & $\mathrm{ND}$ & $\mathrm{ND}$ & 0.051 \\
\hline LWG (g/day) & 54 & 67 & $\mathrm{ND}$ & $\mathrm{ND}$ & 9.3 \\
\hline Wool growth (g/day) & 13.2 & 11.1 & $\mathrm{ND}$ & $\mathrm{ND}$ & 0.66 \\
\hline
\end{tabular}

3 Douglas et al. (1995), 4 Douglas et al (1999), 5 Wang et al. (1996a); 6 Min et al. (1998).

$\mathrm{CT}=$ condensed tannins, $\mathrm{PEG}=$ polythylene glycol, SE = standard error, $\mathrm{ND}=$ not determined.

${ }^{1}$ Initial liveweight.

${ }^{2}$ Daily green forage allowance.

spring of 2000 increased lamb growth $(258 \mathrm{cf} .189 \mathrm{~g} /$ day) and increased weaning weight (36.2 cf. $30.1 \mathrm{~kg})$ (Ramírez-Restrepo et al. 2002). This was achieved in the absence of pre-lambing anthelmintic drenching of the ewes; faecal dag scores up to weaning were lower for both ewes and lambs grazing $L$. corniculatus than for their counterparts grazing pasture. Similar results were found when the experiment was repeated in the spring of 2002.

An experiment over the summer of 2002-2003 evaluated the L. corniculatus effect on growth of weaned lambs over 14 weeks, relative to comparable lambs grazing perennial ryegrass/white clover pasture. This also examined the possibility of reducing anthelmintic drench input (Figure 1). Lambs grazing each forage were drenched either at 4-week intervals (4 drenches overall; regularly-drenched group) or were given one drench only at day 58, when faecal egg counts (FEC) rose to $1000 \mathrm{eggs} / \mathrm{g}$ (restricted-drench group). Regularly-drenched and restricted-drench lambs grazed separate areas of each forage, under rotational grazing.

There was an interaction between treatment $x$ time $(\mathrm{P}<0.001)$ because liveweight gain $(\mathrm{LWG})$ throughout 
Table 2 The effect of grazing ewes on Lotus corniculatus or perennial ryegrass/white clover (pasture), and of supplmentation with polyethylene glycol on maximum ovulation rate, wool production and on liveweight gain.

\begin{tabular}{|c|c|c|c|c|c|c|}
\hline & \multirow[t]{2}{*}{ Experiment ${ }^{1}$} & \multirow{2}{*}{$\begin{array}{l}\text { Pasture } \\
+/- \text { PEG }\end{array}$} & \multicolumn{2}{|c|}{ L. corniculatus } & \multirow[b]{2}{*}{$\begin{array}{l}\text { Legume } \\
\text { Effect }(\%)^{2}\end{array}$} & \multirow[b]{2}{*}{$\begin{array}{c}\text { CT } \\
\text { Effect }(\%)^{3}\end{array}$} \\
\hline & & & $\begin{array}{l}\text { Supplemented } \\
\text { PEG }\end{array}$ & CTActing & & \\
\hline \multicolumn{7}{|l|}{ (Ovulation rate) } \\
\hline Min et al (1999) & 5 & 1.33 & 1.46 & 1.76 & 9.8 & 22.6 \\
\hline Luque et al (2000) & 6 & 1.45 & 1.66 & 1.64 & 14.5 & 0 \\
\hline Min et al (2001) & 7 & 1.48 & 1.58 & 1.79 & 6.6 & 14.2 \\
\hline Mean & & 1.42 & 1.57 & 1.73 & 10.3 & 12.3 \\
\hline \multicolumn{7}{|c|}{ (Clean fleece weight; kg) } \\
\hline Min et al. (1999) & 5 & 1.12 & 1.31 & 1.35 & 17.0 & 3.6 \\
\hline Luque et al. (2000) & 6 & 1.54 & 1.69 & 1.73 & 9.7 & 2.6 \\
\hline Min et al. (2001) & 7 & 1.41 & 1.61 & 1.71 & 14.2 & 7.1 \\
\hline Mean & & 1.36 & 1.54 & 1.60 & 13.6 & 4.4 \\
\hline \multicolumn{7}{|c|}{ (Liveweight gain; g/day) } \\
\hline Min et al (1999) & 5 & 12 & 34 & 40 & & \\
\hline Luque et al (2000) & 6 & -12 & -20 & -25 & & \\
\hline Min et al (2001) & 7 & 43 & 16 & 22 & & \\
\hline
\end{tabular}

PEG = polythylene glycol, $\mathrm{CT}=$ condensed tannins.

${ }^{1}$ Initial liveweight was 54, 60 and $53 \mathrm{~kg}$ in Experiments 5, 6 and 7, respectively.

${ }^{2}$ Calculated as: (L. corniculatus PEG - Pasture ) $\times 100$

Pasture

${ }^{3}$ Calculated as: (L. corniculatus CT Acting - Lotus PEG) $\times 100$

$$
\text { Pasture }
$$

Table 3 The effect of mating on Lotus corniculatus in 2001 on the reproductive performance (\% ewes mated) of ewes on Massey University dryland farm in the Wairarapa. The period of grazing on lotus was 9 weeks from 13 February to 16 April 2002 (rams were introduced on 15 February and removed on 16 April).

\begin{tabular}{lccc}
\hline & L. corniculatus & Pasture & Significance \\
\hline Scanning (\%) & 179 & 170 & $*$ \\
Lambing (\%) & 175 & 159 & $*$ \\
Docking (\%) & 159 & 130 & $*$ \\
Weaning (\%) & 155 & 123 & NS \\
Birth weight $(\mathrm{kg})$ & 5.5 & 5.5 & $\mathrm{NS}$ \\
Weaning weight $(\mathrm{kg})$ & 32.1 & 32.3 & $*$ \\
Fleece weight $(\mathrm{kg})$ & 3.1 & 2.9 & \\
Lamb mortality: & & & $*$ \\
Lambing to weaning (\%) & 11.4 & 22.6 & \\
\hline
\end{tabular}

Ramíerz-Restrepo et al. unpublished.

NS non-significant.

* $\quad(P<0.05)$.

** $\quad(P<0.01)$ 
the entire experiment was higher for regularlydrenched than restricted-drench lambs grazing $L$. corniculatus (298 cf. 228 g/day; $\mathrm{P}<0.001$ ), whereas for lambs grazing pasture, LWG was similar for both groups (201 cf. $187 \mathrm{~g} /$ day). LWG of lotus restricteddrench lambs was also higher than either pasture group. Final liveweight after 95 days was $7.0 \mathrm{~kg}$ greater $(\mathrm{P}<0.001)$ for regularly- drenched than restricted-drench lambs grazing L. corniculatus $(57.2$ cf. $50.1 \mathrm{~kg})$, but was similar $(\mathrm{P}<0.82)$ for both drench groups grazing pasture $(47.8 \mathrm{cf} .47 .5 \mathrm{~kg})$. Final liveweight of $L$. corniculatus restricted-drench lambs was $2.6 \mathrm{~kg}$ heavier $(\mathrm{P}<0.005)$ than that of pasture restricted-drench lambs and $2.4 \mathrm{~kg}$ greater than that

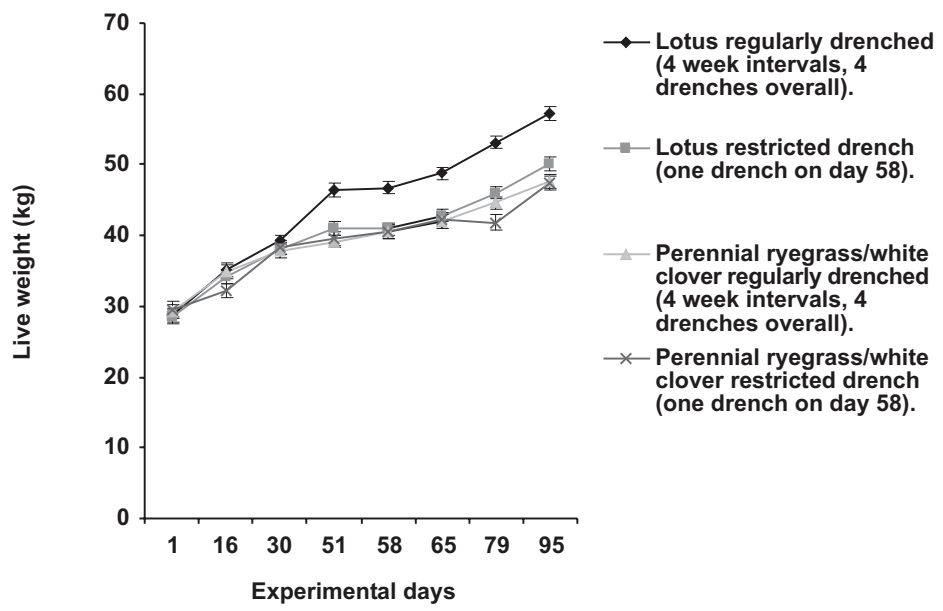

Figure 1 The effect of withdrawing anthelmintic drench upon the growth of weaned lambs grazing Lotus corniculatus or perennial ryegrass-based pasture for 95 days over the 2002/2003 summer at Riverside Farm, Masterton, Wairarapa. Green DM allowance was $6.5 \mathrm{~kg} / \mathrm{lamb} /$ day for all treatments. The experiment commenced on 18 November 2002 and concluded on 21 February 2003. (Ramírez-Restrepo et al. unpublished). SEM for the four treatments ranged from 0.92 to $1.00 \mathrm{~kg}$.

of pasture regularly-drenched lambs $(\mathrm{P}<0.054)$.

These results show growth in the regularly drenched L. corniculatus lambs approached the Sheep Industry target of $400 \mathrm{~g} /$ day during the first month. Under field conditions, the CT in L. corniculatus did not seem to be particularly effective for counteracting parasites, as both undrenched groups required drenching on day 58 when faecal egg counts exceeded $1000 / \mathrm{g}$ for both groups. However, restricted-drench, lotus-fed lambs grew at higher rates under a parasite challenge, probably due in part to better protein absorption from the action of $\mathrm{CT}$.

\section{Agronomy of Lotus corniculatus in the Wairarapa}

The annual and seasonal DM production of $L$. corniculatus at Riverside Farm near Masterton has been similar to that of perennial ryegrass and white clover pasture. The annual production of $L$. corniculatus and perennial ryegrass in 2000-2001 were 953 and $8640 \mathrm{~kg} \mathrm{DM} / \mathrm{ha}$, respectively, (RamírezRestrepo unpublished) and they had similar patterns of seasonal production. The mean seasonal percentage production in spring, summer, autumn and winter was 49, 40, 8 and 4\% for L. corniculatus and $55,30,9$ and $6 \%$ for perennial ryegrass/white clover pasture. The L. corniculatus has remained productive and persistent for three years, in contrast to L. corniculatus grown on heavy soil in the Manawatu that failed to persist beyond two years without regular use of herbicide.

Successful establishment of $L$. corniculatus in the experimental programme has been achieved by the use of at least $20 \mathrm{~kg} / \mathrm{ha}$ of coated seed, to obtain rapid ground cover and minimise weed invasion, and sowing in either late February, early March, or in spring. In addition, sowing depth must be no greater than $10 \mathrm{~mm}$, which although possible by direct drilling, is easier to manage with a roller drill. The only establishment failure in the programme resulted from the one occasion direct drilling was used, which resulted in the seed being sown too deep.

Early weed control of $L$. corniculatus with Preside (a.i. flumetsulam) has been successful, with Gallant (a.i. haloxyfop) used to remove invading grasses, and either Sencor (a.i. metribuzin) or a clean up with a paraquat/diquat herbicide used in late winter (August). A paraquat/diquat herbicide is cheaper but delays spring growth. Thistles have proved to be a problem in established L. corniculatus stands due to the history of the paddocks, but have been cheaply and effectively controlled by boom wick application of glyphosate. Pre-emergent herbicides have not been used in the experimental programme. 
The regrowth after grazing of $L$. corniculatus is from both primary shoots from the crown and from secondary shoots on primary shoots that are on the ground. Regrowth is slow if the prostrate primary shoots are grazed (Ayala 2001). First grazing of $L$. corniculatus occurred after the network of primary shoots along the ground established and the sward was at least $0.10 \mathrm{~m}$ tall (Ayala 2001). Grazing management in spring was a monthly rotation, with sheep in each break for one week. Pre-grazing herbage mass in spring was approximately $3500 \mathrm{~kg}$ $\mathrm{DM} / \mathrm{ha}$, or $15-20 \mathrm{~cm}$ tall, and the post-grazing herbage mass was $2000 \mathrm{~kg} \mathrm{DM} / \mathrm{ha}$, or $10-15 \mathrm{~cm}$. In summer, the pre- and post-grazing mass was 2000 and $900 \mathrm{~kg}$ $\mathrm{DM} / \mathrm{ha}$, respectively. There were typically eight grazings per year on L. corniculatus (RestrepoRamirez et al. unpublished).

Apparent intake of the sheep on L. corniculatus has been greater than those sheep on the perennial ryegrass/white clover treatment, notably in spring, which suggests that L. corniculatus will be grazed harder by ad lib-fed sheep than perennial ryegrass/ white clover unless the post-grazing herbage mass is controlled. Sheep were observed to mainly eat the leaves of L. corniculatus under lax grazing, but when pushed they ate the stems. As was also reported by Ayala (2001), grazing that removed a substantial proportion of the prostrate primary shoots severely delayed regrowth and encouraged weed ingression.

\section{Conclusion}

Following effective establishment, our stands of $L$. corniculatus have thus far lasted for 3 years in the Wairarapa. They have out-yielded normal pasture by about $10 \%$ and have greater summer production.

From the results obtained to date, the first priority for using L. corniculatus in dryland farming is to increase lambing percentage and weaning percentage, as 6-9 weeks of feeding during mating is all that is necessary to increase whole year productivity.

A second priority is to feed $L$.corniculatus to lactating ewes and their lambs during spring, to increase lamb weaning weight and hence the proportion of lambs drafted early. This can be achieved whilst also eliminating pre-lambing anthelmintic drenching. The third priority for use of $L$.corniculatus under dryland farming is to increase the growth of weaned lambs over summer. However, for maximum growth rates, regular anthelmintic drenching proved necessary, though the growth rates of reduced drench lambs grazing Lotus still exceeded that of regularly drenched lambs grazing pasture.

These results show that $L$.corniculatus has potential as a specialist feed in dryland farming systems.

\section{ACKNOWLEDGEMENTS}

We thank Meat \& Wool Innovations for financial support of the Massey L .corniculatus programme, both at Palmerston North and in the Wairarapa. We thank the New Zealand Ministry of Foreign Affairs and Trade, Massey University and the Colombian Agriculture Research Agency (CORPOICA) for provision of scholarship support to Carlos A. Ramíirez-Restrepo.

\section{REFERENCES}

Ayala, W. 2001. Defoliation management of birdsfoot trefoil (Lotus corniculatus). Unpublished PhD thesis , Massey University.

Barry, T.N.; McNabb, W.C. 1999. The implications of condensed tannins on the nutritive value of temperate forages fed to ruminants. British Journal of Nutrition 81: 263-272.

Barry, T.N.; McNeill, D.M.; McNabb, W.C. 2001. Plant secondary compounds; their impact on forage nutritive value and upon animal production. pp 445-452. In: Proceedings of the XIX International Grassland Congress. Ed A.M.C. Filko. Brazilian Society of Animal Husbandry.

Douglas, G.B.; Stienezen, M.; Waghorn, G.C.; Foote, A.G. 1999. Effect of condensed tannins in birdsfoot trefoil and sulla on body weight, carcass fat depth and wool growth of lambs in New Zealand. New Zealand Journal of Agricultural Research 42: 55-64.

Douglas, G.B.; Wang, Y.; Waghorn, G.C.; Barry, T.N.; Purchas, R.W.; Foote, A.G. Wilson, G.F. 1995. Liveweight gain and wool production of sheep grazing Lotus corniculatus and lucerne. New Zealand Journal of Agricultural Research 38: 95-104.

Jones, W.T.; Mangan, J.L. 1977. Complexes of the condensed tannins of sainfoin (Onobrychis viciifolia scop.) with fraction 1 leaf protein and with submaxillary mucoprotein, and their reversal by polyethylene glycol and $\mathrm{pH}$. Journal of the Science of Food and Agriculture 28: 126-136.

Luque, A.; Barry, T.N.; McNabb, W.C.; Kemp, P.D.; McDonald, M.F. 2000. The effect of length feeding on Lotus corniculatus during late summer/autumn upon reproductive efficiency and wool production in ewes. Australian Journal of Agricultural 
Research 51: 385-391.

Min, B.R.; Barry, T.N.; McNabb, W.C.; Kemp, P.D. 1998. The effects of condensed tannins on the production of wool and on its processing characteristics in sheep grazing Lotus corniculatus. Australian Journal of Agricultural Research 49: 597-605.

Min, B.R.; McNabb, W.C.; Barry T.N.; Kemp, P.D.; Waghorn, G.C.; McDonald, M.F. 1999. The effect of condensed tannins in Lotus corniculatus upon reproductive efficiency and wool production in sheep during the late summer and autumn. Journal of Agricultural Science, Cambridge 132: 323-334.

Min, B.R. ;Fernandez, J.M.; Barry, T.N.; McNabb, W.C.; Kemp, P.D. 2001. The effect of condensed tannins in Lotus corniculatus upon reproductive efficiency and wool production in ewes during autumn. Animal Feed Science and Technology 92: 185-202.

Min, B.R.; Barry, T.N.; Attwood, G.T.; McNabb, W.C. 2003. The effect of condensed tannins on the nutrition and health of ruminants fed fresh temperate forages; a review. Animal Feed Science and Technology 106: 3-19.

Ramírez-Restrepo, C.A.; Barry, T.N.; Lopez-Villalobos, N.; Kemp, P.D.; Pomroy, W.E.; McNabb, W.C.;
Harvey, T.G.; Shadbolt, N.M. 2002. Use of Lotus corniculatus to increase sheep production under commercial dryland farming conditions without the use of anthelmintics. Proceedings of the New Zealand Society of Animal Production 62: 177178.

Terrill, T.H.; Douglas, G.B.; Foote, A.G.; Purchas, R.W.; Wilson, G.F.; Barry, T.N. 1992. Effect of condensed tannin upon body growth, wool growth and rumen metabolism in sheep grazing sulla and perennial pasture. Journal of Agricultural Science, Cambridge 119: 265-273.

Waghorn, G.C.; Ulyatt, M.J.; John, A.; Fisher, M.T. 1987. The effect of condensed tannins on the site of digestion of amino acids and other nutrients in sheep fed on Lotus corniculatus. British Journal of Nutriton 57: 115-126.

Wang, Y.; Douglas, G.B.; Waghorn, G.C.; Barry, T.N.; Foote, A.G. 1996a. Effect of condensed tannins upon the performance of lambs grazing Lotus corniculatus and lucerne. Journal of Agricultural Science, Cambridge 126: 87-98.

Wang, Y.; Douglas, G.B.; Waghorn, G.C.; Barry, T.N.; Foote, A.G. 1996b. Effect of condensed tannins in Lotus corniculatus upon lactation performance in ewes. Journal of Agricultural Science, Cambridge 126: 535-362. 


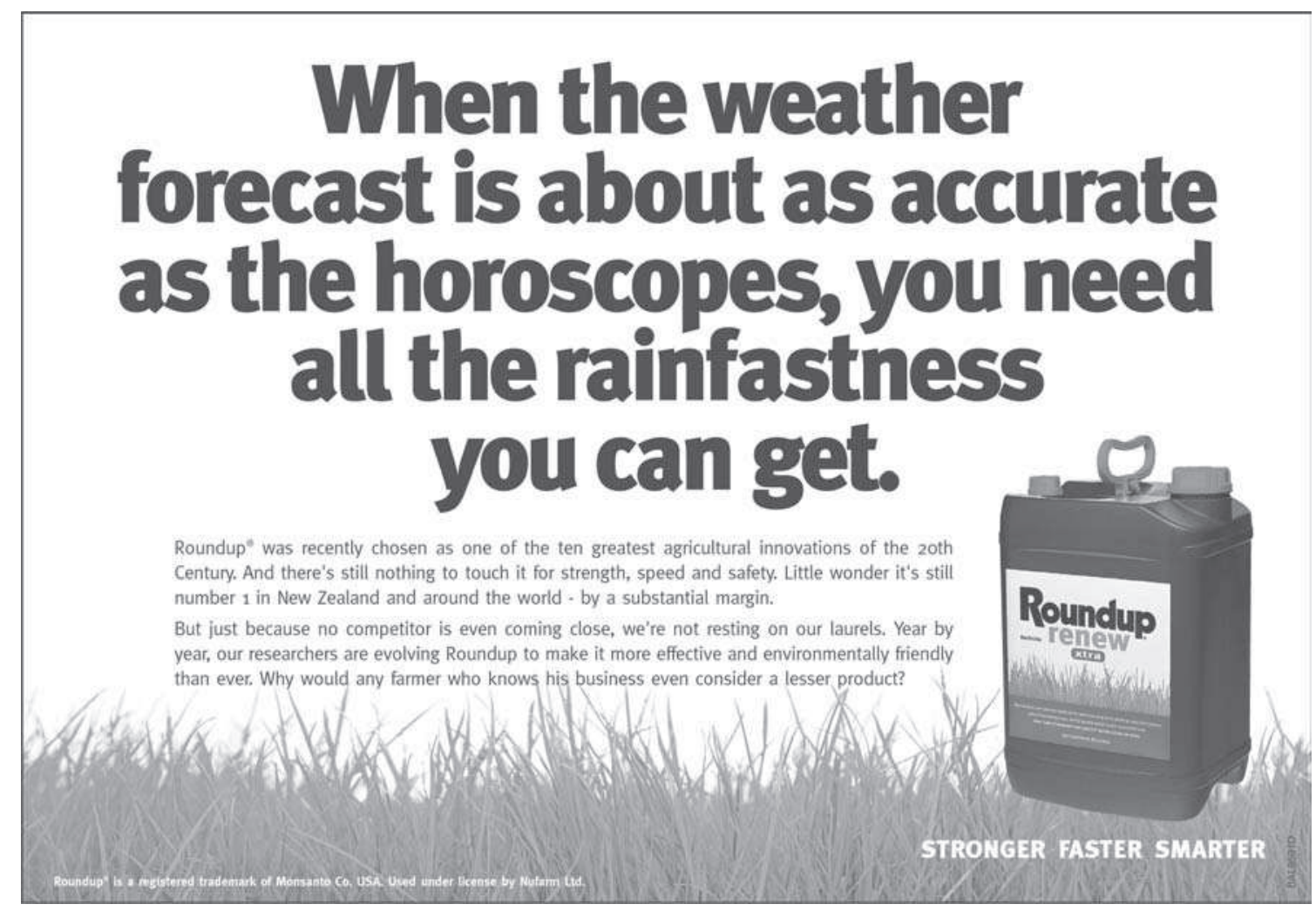

